\title{
REVIEWS
}

\section{CASUALTY ACTUARIAL SOCIETY}

The 1958 Proceedings contains a Presidential address by Dudley M. Pruitt and nine technical papers, resumés of which follow.

The Seat of Wisdom. Presidential Address by Dudley M. Pruitr. A discussion, with all the charm of which Mr. Pruitt is such a master, of the duties of a company actuary.

Automobile Bodily Injury Liability Rates-Use of ro/20 Experience in the Establishment of Territorial Relativities, by MARTIN BONDY.

In the United States of America and in Canada a maximum limit of liability is included in all liability insurance policies and in the past 5/ro limits ( $\$ 5,000$ each person and $\$ 10,000$ each occurrence) was the legal minimum and the most common coverage issued. For some several years however the purchase or at least ro/2o limits has been common and is now the minimum in New York State. The territorial rate differentials used are based on 5/ io experience but now we are beginning to observe that the results obtained by the use of 10/20 experience may differ from those derived from 5/10 experience. The author discusses the extent and the reasons for this difference.

The Employment of Property and Casualty Actuaries, by L. H. LongLEY-COOK.

This brief paper analyzes the employment of fellows of the Casualty Actuarial Society, the only Society devoted entirely to the non-life actuarial field to which admission is by examination. On December 3I, I957 the Society had I 86 fellows. Some were employed in life insurance work or were retired. Of the remainder, 6 were in State employment, 23 were employed by rating and advisory bureaus and 78 were employed by fire and casualty companies. A further ${ }_{5} 5$ were in consulting and similar work.

The Advantages of Calendar-Accident Year Experience and the Need for Appropriate Trend and Projection Factors in the Determination of Automobile Liability Rates, by PAUL BenBrook

This paper gives a clear outline of the advantages to be realized by using the calendar-accident year experience instead of policy year experience and discusses the reasons why trend and projection factors are essential if rate levels are to be proper during the period to which they are to apply.

The author finds that the countrywide average cost of automobile liability losses, both bodily injury and property damage, have increased about three times as much as the cost of living index during the post-war period. These increases in liability losses are due to several factors. The chief factors are (I) the increased claim consciousness of the public, (2) the liberal jury awards, (3) the effect of such liberal awards on the settlement value of claims that do not go to trial, (4) the failure of juries to follow the rules of negligence, and $(5)$ the design and power of the present-day automobile which has increased the frequency and the severity of accidents. 